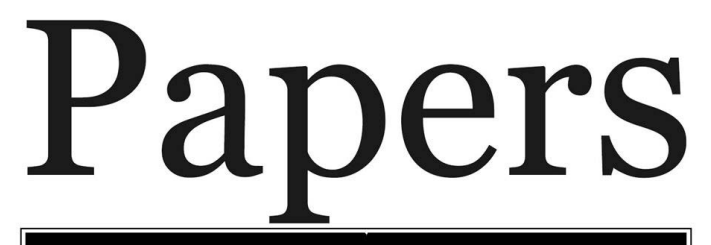

Explorations into Children's Literature

\title{
“Why would a dead girl lie?”: Hannah Baker as willful child 'come to voice' in 13 Reasons Why
}

\author{
Amber Moore - University of British Columbia
}

\begin{abstract}
This paper examines representations of hostile and benevolent sexism in the young adult novel 13 Reasons Why (Asher, 2007), and how the female protagonist, Hannah Baker, resisted such manifestations of rape culture. Hannah exercised such resistance by taking on a willful girl-child (Ahmed, 2014) subject position through the creation of her métissage of taped testimonial messages recorded for thirteen peers who in some way influenced her death by suicide. As such, her project enabled Hannah to 'come to voice' (hooks, 1994) particularly in response to three sexist characters - Tyler, Bryce, and part-time narrator, Clay.
\end{abstract}

Keywords: 13 Reasons Why, Sara Ahmed, bell hooks, métissage, young adult literature, willful child

Introduction: Hannah's will

I sat there with my will,
my watery will.
Nothing else for company

(Alvi, 2008, p. 22).

The first few moments of Hannah's voice in the popular and acclaimed young adult (YA) novel, 13 Reasons Why (Asher, 2007), aptly captures her tone as well as that of the story as a 
whole: 'I hope you're ready; because I'm about to tell you...' (p. 7). She is unapologetic, unwavering, and unstoppable; she will be heard. The book, turned into a popular Netflix series in 2017, commences shortly after high school student Hannah Baker's death by suicide and is narrated both by both Hannah and heartbroken Clay Jensen. It chronicles Clay listening to Hannah's cassette tape recordings detailing thirteen reasons why she has chosen to take her own life - a kind of suicide note. Throughout, readers are confronted with several difficult issues including: bullying, drinking and driving, heartbreak, rape, and suicide, among others, all somehow entangled by Hannah's experiences. This story is significant because Hannah functions as a kind of 'wound that speaks' (Caruth, 1995, p. 8), and moreover, 'We need to let [the willful child] create more of an impression' (Ahmed, 2014, p. 57).

Despite the tragic trauma(s) in Hannah's narrative, this paper argues that even though Hannah dies by suicide, Hannah nevertheless authors herself as a kind of resistant feminist 'willful child' (Ahmed, 2014) at the end of her life. She does so by employing the cassette tapes as tools for braiding a subversive métissage (Lionnet, 1989; Hasbe-Ludt, Chambers, \& Leggo, 2009; Zuss, 1997) of 13 testimonial messages that function to combat both hostile and benevolent sexism (Glicke \& Fiske, 1996) by challenging the male gaze (Mulvey, 1975) and exercising her own optic agency to bear witness to sexual violence. Her messages map a 'coming to voice' (hooks, 1994), enacting a kind of 'feminism as screaming in order to be heard' (Ahmed, 2017, p. 73). As such, in this paper, I argue that Hannah, as a kind of Ahmed's (2014) willful child subject, 'comes to voice' through three central messages to characters Tyler, Bryce, and Clay, in her resistant recorded métissage of 'reasons why' she wanted to die. It is also worth noting that this work is inspired by Marshall's (2009) examination of YA sexual assault story Wolf, where she addresses a lack of focus on 'detail[s] [of] the damaged man' (p. 230), and so, I aim to 'foreground the rapacious' (p. 219) adolescent male characters in this project. Ultimately, Hannah seats herself firmly in the category of 'the many willful girls that haunt literature' whom 'we might share affection for' (Ahmed, 2014, p. 3) and the young men that harm her will not 'disappear... from view' (Marshall, 2009, p. 229) here. 


\section{Theoretical framework: Sara Ahmed \& bell hooks' feminisms}

\section{Sara Ahmed's 'willful subject'}

Ahmed (2017) asserts: 'the willful child: she has a story to tell' (p. 67). Using a Grimm story, The Willful Child, as an anchor point, Ahmed reflects upon how '...what is striking about this story is how willfulness persists even after death' (p. 67). This particularly connects to Hannah Baker's impact because 'to bring materials together as a willfulness archive might create an even stronger impression of the willful subject' (Ahmed, 2014, p. 17). Willful subject Hannah is certainly 'a powerful container' (p. 17) and willfulness can be wielded as a feminist tool, as evidenced by this novel.

Ahmed's work has sparked many discussions on willfulness (see, for example, 2012; 2014; 2017), however, her 'rousing' (Simpson, 2014, p. 752), Willful Subjects (Ahmed, 2014) is a particularly deep dive into how this characteristic is impactful and can foster change; willfullnes, after all, is an 'opportunity' - 'an act that stands out because it stands apart from the ordinary' (p. 152). It is important to note that Ahmed deliberately uses the American spelling of 'willful,' as it 'allows us to see the 'will' in 'willful' (p. 205). She defines willfulness broadly; it includes being 'compromising' (p. 1), 'persisten[t]' (p. 2), 'a problem' (p. 3), and 'too assertive, too pushy' (p. 20). She also discusses how 'There is a family of words around willfulness (stubborn, obstinate, rude, reckless) that creates a structure of resemblance (we feel we know what she is like)' (p. 150, original emphasis). Ahmed, however, is more so interested in 'what willfulness is doing' (p. 17). While certainly, 'to be willful is to be a problem' (p. 3) - willful folks are often perceived as troublemakers, or, as 'feminist killjoys' it is equally important to remember that 'will works as an idea that converts into a narrative' (p. 14). This is the doing of willfulness, an act or even 'craft' (p. 133) that Hannah takes up in her métissage project. In the very act of creating her cassette tapes, Hannah demonstrates that she is a 'willful girl-child... one who insists on getting her own way, who comes to you with her own explanations of what it is that she is doing' (p. 21). 
A few qualities of the willful subject especially connect with Hannah's narrative métissage. First, the willful child can be 'part of our own history, embodied as memory' and understood as 'a ghostly figure, a trace or impression of a person' (Ahmed, 2014, p. 17). Next, the willful child 'becomes a tool in the history of the education of will,' and finally, 'willfulness can be actively claimed... [it is] a counter[ing]' and 'difficult' endeavour (p. 20). For example, because the willful child can be a tool for change, Ahmed writes that willfulness can be thought of 'as a political art' - a way to become 'crafty' (p. 133). She urges us to consider willfulness as an audacious, creative 'standing against' (p. 134).

Hannah's métissage of thirteen braided messages that speak out against those who have wronged her are thus a creative and audacious example of 'standing against' from the positionality of the willful girl-child subject. After all, as Ahmed asserts: 'Willfulness [is] that which is striking' (p. 47) - it is 'electric" (Ahmed, 2017, p. 214).

\section{bell hooks' 'coming to voice'}

To say that bell hooks is prolific is an understatement; hooks has been influencing and advancing feminist theories, politics, and practices for decades (Valdivia, 2002). Especially compelling is her take on the notion of 'coming to voice,' arguing that when 'apply[ing] the theory of coming to voice... especially in relation to understanding domination and creating a critical consciousness, meaningful transformation takes place for self and society' (hooks, 2015, p. xi). She describes 'coming to voice' as a helpful way to 'mov[e] from silence to speech as a revolutionary gesture' - it is 'an act of resistance' (p. 12), an 'affirmation of struggle' (p. 18) - and exactly why her conception of it is so useful for framing Hannah's willful métissage.

She also delves into what it means to 'come to voice,' particularly within the context of education (hooks, 1994). Because Hannah's story is anchored in the relationships that she fosters at school, hooks' ideas are especially valuable. For instance, hooks insists that a central way 'to build community in the classroom [is by]... recognizing the value of each individual voice' (p. 40) because 'To hear each other.... To listen to one another, is an 
exercise in recognition' (p. 41). While hooks is not blind to the pain that so many students feel during such listening and speaking practices, she nevertheless asserts that 'coming to voice' is worthwhile and transformative; indeed, 'while it is not easy to name our pain' ( $p$. 74), 'Personal testimony, personal experience, is such a fertile ground for the production of liberatory feminist theory because it usually forms the base of our theory making' (p. 70). As such, hooks asserts, 'coming to voice' is not simply relaying one's experiences, but rather, 'It is using that telling strategically - to come to voice so you can also speak freely about other subjects' (p. 148). With this in mind, it is clear that Hannah powerfully does 'come to voice,' forever changing those who listen to it. She uses her tapes to address difficult subject matter, including sexual harassment, assault, bullying, and suicide, strategically positioning her listeners to critically consider their actions, prompting guilt, fear, regret, anxiety, and grief. Thus 'willing [is] an activity that is bound up in a project' (Ahmed, 2014, p. 61), and willful Hannah executes an impactful project to school her classmates while subsequently bringing herself to voice; indeed, 'voices can be arms, raised in the hope of disturbing the ground' (p. 141).

\section{Conceptual frameworks: Métissage as pushback against hostile $\&$ benevolent sexism}

\section{Métissage as strategy}

Métissage (Lionnet, 1989; Hasbe-Ludt, Chambers, \& Leggo, 2009; Zuss, 1997) - 'a concept... a practice' (Lionnet, 1989, p. 6) and a 'praxis' (p. 8) - is useful for understanding the significance of Hannah Baker's 13 messages. Métissage, a kind of autobiographical production, encompasses many characteristics that resonate in Hannah's generative project; it is all at once 'subversive' (p. 12), 'messy' (Hasbe-Ludt, Chambers, \& Leggo, 2009), 'a process of questioning' (p. 2), 'creative, artistic' (p. 7), and 'a contact zone' (p. 35), among other qualities. For instance, Hasbe-Ludt, Chambers, \& Leggo (2009) demonstrate how literary métissage is a powerful way for engaging with life writing. As all three authors braid life stories, they create an 'intermingling,' a kind of 'way to generate, represent and critique knowledge' (pp. 34-5). When applied as research, literary métissage 'not only describes experience; it is a strategy for interpreting those experiences as documented' (pp. 34-5). 
Using métissage to understand Hannah's 13 reasons makes sense with her willful girl-child (Ahmed, 2014) subjectivity for a number of reasons, starting with the notion that the work of the willful is 'not a straight, but wayward line, as it must be if we are to find each other in the puzzle of what unfolds' (p. 21). Hannah's 'puzzling' storytelling demonstrates that métissage can also resistant and fear-inducing; as Hasbe-Ludt, Chambers, and Leggo (2009) assert, 'Writing is hunting' (p. 71) - after all, 'words can smother us, enrage us; they can leave us full or empty. When they touch us, they create an impression' (Ahmed, 2014, p. 17). Therefore, métissage is also a strategy (Zuss, 1997).

Hannah's métissage certainly demonstrates 'The transformative possibilities of journeying through métissage' (p. 8), and how such braided stories hold 'Power involv[ing] the capacity to carry out an action despite the will of others' (Ahmed, 2014, p. 54) - others who would will her stories into silence.

\section{Hostile \& benevolent sexism}

Sexism is incredibly dangerous; as Valenti (2016) argues, it 'impacts not just our lives, but our very sense of self... For some, it's a more violent and literal experience than I could imagine or explain' (p. 3). Hannah experiences exactly this kind of violent and literal manifestation of sexism - hostile sexism, chiefly at the hands of Tyler and Bryce, and benevolent sexism with Clay.

Glick and Fiske (1996) differentiate between these two forms of sexism, first arguing that hostile sexism 'needs little explanation' (p. 491), as it encompasses a range of 'prevalent' (p. 492) dangers including harassment, assault, and violences. They define benevolent sexism as:

....a set of interrelated attitudes toward women that are sexist in terms of viewing women stereotypically and in restricted roles but that are subjectively positive in 
feeling tone (for the perceiver) and also tend to elicit behaviours typically categorized as prosocial (e.g. helping) of intimacy (self-disclosure). (p. 491)

Benevolent sexism 'portrays women as the 'pure,' the 'better' sex - idealized caregivers' reinforcing 'the idea that women should be protected and financially provided for by men' (Becker \& Swim, 2011, p. 228). It can be easily disregarded as a positive orientation; however, across diverse research, its dangers are apparent (see, for example, Expo' sito, Herrera, \& Moya, 2010; Fraser, 2015; Glick et al., 2000). In considering benevolent sexism and its connection to sexual harassment and assault, it can manifest in troubling ways. For instance, Fraser (2015) confronts the 'obvious' link between rape and misogyny, yet: 'the role of ostensibly benevolent sexism in sexual violence is less intuitive' (p. 143). Operations of benevolent sexism can reveal how rape culture persists (p. 147) and its 'insidiousness' makes it 'as dangerous as misogyny' (Glick and Friske, 1996, p. 149). Thus, benevolent sexism is useful when considering the degree to which sexism is 'a multidimensional construct' (Glick \& Friske, 1996, p. 491).

While manifestations of both benevolent and hostile sexism will be explored through Hannah's experiences with Tyler, Bryce, and Clay, these discussions are unfortunately not exhaustive, making this novel ripe for continued feminist analysis.

\section{Challenging hostile sexism: Tyler, Bryce, and their abusive gazes}

\section{Tom Tyler}

Tyler, an early 'messy thread' (Hasbe-Ludt, Chambers, \& Leggo, 2009, p. 1) of Hannah's métissage of messages, enacts a particularly heinous form of hostile sexism - one that keeps Hannah from feeling safe in her own bedroom, which should be a 'haven' space, 'distanced from the pressures and activities of daily life' (Ronnberg \& Martin, 2010, p. 598). Being the school newspaper's photographer, Tyler is well-equipped with expensive camera gear which he uses to repeatedly invade Hannah's privacy. 
At first, Hannah found Tyler unassuming, admitting 'I thought you were the nicest guy... Everyone thought so' and saw him as 'quiet' (Asher, 2007, p. 71). However, his quiet nature seems to inform his 'creep[iness],' when he wielded what Mulvey (1975) calls 'the male gaze,' as a weapon of harassment by acting as an 'amateur peeping Tom' (p. 76), spying on Hannah in her bedroom at night and taking photos of her. Mulvey (1975) foregrounds her famous film studies discussion of the male gaze as one that is produced 'In a world ordered by sexual imbalance' where 'pleasure in looking has been split between active/male and passive/female' (p. 11). In such a world, as typically found in cinema, 'women are simultaneously looked at and displayed,' fostering a 'to-be-looked-at-ness' wherein women are rendered as 'erotic spectacle[s]' (p. 11). Tyler's role as 'creepy' peeping Tom certainly embodies the male gaze and yet, willful child Hannah nevertheless resists his sexualizing and reducing of her to object status; she interrupts the typical narrative that 'supports the man's role as the active one forwarding the story, making things happen' (p. 12). Rather, she 'comes to voice' and exacts revenge, punishing his dangerous 'gazing.'

To begin with, Hannah admits that even her 'flipping' of the gaze, of 'trying to get closer to you, Tyler' feels unnatural - she 'feel[s] a little creepy' (p. 75); it feels strange for her to 'try[] to understand the excitement of staring through someone's bedroom. Watching someone who doesn't know they're being watched. Trying to catch them...' (p. 75). This might be indicative of how sometimes, 'Willing can be anxious' (Ahmed, 2014, p. 37) work. She then accuses: 'You started peeping way before I caught you' (Asher, 2007, p. 78) and muses about how long he has been stalking her. At first, though she doesn't have proof of being watched and feels 'freaked out' (p. 80). She insists she:

...wasn't dumb enough to change in front of the window... I pulled the blankets over my body and undressed beneath them. Then I put on my pajamas, doing everything as slowly as possible, afraid whoever was outside might snap another picture. After all, I wasn't totally sure what a Peeping Tom got off on. (p. 80) 
Despite her anxiety, in this moment Hannah interrupts his harassing gaze, thus demonstrating her capability to 'determin[e] what happens; [the willful child] is the ruler of the house' (Ahmed, 2014, p. 74). Hannah strategically uses her space and, like a 'ruler,' determines the boundaries of her domain so that her territory - her bodily integrity - is not infringed upon, by blocking sightlines with walls and blankets. Here, Hannah importantly 'strengthens her will,' harnessing how her 'will is how a subject can be elevated above a situation' (p. 75) as she uses her wits to outsmart her peeping Tom. Will then becomes Hannah's 'internal resource' (p. 75), utilised to evade further intrusion; certainly, in this moment, she 'wasn't dumb' (Asher, 2007, p. 80).

Hannah's willfulness as a tool is next employed when she seethingly anticipates potential victim blaming, snarling:

'So why was it so easy for Tyler to see into my room to begin with? Is that what you're asking? Do I always sleep with my shades wide open? Good question, victim-blamers' (p. 82).

Here, her 'coming to voice' is an overt '...act of resistance' (hooks, 1994, p. 12); victim blaming, which includes 'explicitly hold[ing] survivors responsible for the assault, doubt[ing] the veracity of survivors' stories, or minimiz[ing] the severity of the crime' is damaging because 'the experience may feel like a 'second assault' or a 'second rape" (Ahrens, 2006, p. 264). Hannah, however, not only resistantly calls out this atrocious response, but also, just as she resisted Tyler's gaze by hiding under her covers, Hannah resists from the safety of her deathbed, beyond the grave. Here then, it is understandable that Ahmed (2014) characterizes the willful subject as a 'ghostly' (p. 18) figure, able to exact a haunting and foster fear in those who doubt her trauma. In fact, Hannah senses that her haunting 'coming to voice' is devious, even devilish; earlier, she quips about going to hell: 'And you, lucky number thirteen, you can take the tapes straight to hell. Depending on your religion, maybe I'll see you there' (Asher, 2007, p. 9). Often, such a haunting, harsh tone upsets Clay, providing a compelling example of how symbolically 'ghosts may return for many reasons: to 
complete unfinished business [and] to bring messages of import' (Ronnberg \& Martin, 2010, p. 788).

Clay, for example, is paranoid about strangers noticing his discomfort as he listens, admitting: 'I'm too intimidated to look at the people around me. They have to be watching me now. Trying to understand the pained look on my face' (Asher, 2007, p. 89). Clay's anxiousness connects back to Hannah's manipulation of the male gaze; her optic agency is strengthened because she is influencing Clay's 'to-be-looked-at-ness,' making him a 'spectacle' (Mulvey, 1975, p. 11). In this way, Hannah's métissage showcases how willful children both 'creat[e]... an impression [which] can be a technique of power' and can also 'strike' to dislodge an impression' (Ahmed, 2014, p. 140). Hannah uses her project to both make strong impressions as well as 'strike' through and 'dislodge' others because she strives to 'be in control of how people [see her]' (Asher, 2007, p. 19). Relatedly, Hannah also exacts a kind of revenge on Tyler by furthering 'flipping' the gaze by taking on the role of 'peeper' herself; Hannah records her message outside Tyler's bedroom window but notes dissatisfaction: 'Revenge would have been fun... But... standing outside Tyler's window, satisfies nothing.' (p. 83). Again, though resistant, her willfulness shows us that 'the normal mood for willing is anxious' (Ahmed, 2014, p. 37).

Overall, Hannah's métissage chronicles a 'creepy' example of the damaging male gaze, and demonstrates the hostility of that particular form of sexism. Despite this, Hannah is nevertheless triumphant in not only flipping the gaze, but also contending with her anxiety during her willful work to ensure that she successfully 'comes to voice.'

\section{Brutal Bryce}

Ahmed asserts: 'To follow the willful child is to stay proximate to scenes of violence' (pp. 6667), and Hannah's experience(s) with Bryce is a chilling illustration. First, Hannah witnesses Bryce's rape of a classmate. At a party, Hannah drunkenly stumbles into a bedroom closet to hide when others come into the room. Too scared to move, Hannah is trapped and watches, hidden and helpless, while Bryce rapes an unconscious girl on the bed. This scene is 
especially tragic because Hannah blames herself - even though she recognizes the danger in making herself known - but further, her helplessness contributes to her thoughts of suicide:

But to stop it, I felt like I'd have to stop the entire world from spinning. Like things had been out of control for so long that whatever I did hardly mattered anymore. And I couldn't stand all the emotions anymore. I wanted the world to stop... to end. (Asher, 2007, p. 227)

While Hannah is silent in her lonely terror, she describes: 'The bedsprings screaming under his weight. No one heard a thing' (p. 227). These 'screaming' bedsprings seem to aid in Hannah's 'coming to voice,' audibly marking the assault like an accomplice when Hannah is unable to do so herself. After Clay listens to Bryce's tape, he is so upset that he vomits, 'head hanging over the gutter' (p. 228). Perhaps symbolically, this reinforces the idea that Hannah's story, like vomit, is 'stuff that can't be contained' (Ronnberg \& Martin, 2010, p. 736).

Later, Bryce rapes Hannah in a hot tub and even Clay victim-blames her, accusing: 'You wanted your world to collapse around you. You wanted everything to get as dark as possible. And Bryce, you knew, could help you do that' (p. 261), and 'You knew what you were getting into, Hannah' (Asher, 2007, p. 262). Hannah asserts:

For everyone listening, let me be clear: I did not say no or push his hand away. All I did was turn my head, clench my teeth, and fight back tears. And he saw that. He even told me to relax (p. 265).

This moment is important for a few reasons. First, Hannah's insistence of 'let me be clear' demonstrates how as a willful subject, 'Insistence is a form of political labor... [it] can thus be understood as a political grammar' (Ahmed, 2014, p. 149). As such, this particular politicallycharged moment, which arguably represents Hannah's breaking point, tragically also showcases how 'willfulness is a fragile thread that can be stretched only if it is not broken' 
(p. 134); Hannah chronicles: 'When you were done, Bryce... The night was over. I was done' (Asher, 2007, p. 266). Next, it is significant that Hannah's rape takes place in a hot tub -a kind of pool - which, like rape culture, is 'The product of human culture,' bringing to mind the aphorism 'Still waters run deep,' hinting 'at the meanings far beneath the pool's placid surface' (Ronnberg \& Martin, 2010, p. 606). Finally, Hannah's vague description of the rape is curious; indeed, 'What makes it so hard for us to say, "I was raped"?' (Hernandez-Avila, 2005, p. 327). While Hannah does 'come to voice' in many ways, offering accusations including 'Bryce, you had to see my jaw clench. You had to see my tears. Does that shit turn you on?' (Asher, 2007, p. 264), she never explicitly names rape. Naming is important because it is a way to 'demask' (del Guadalupe Davidson \& Yancy, 2009, p. 4), and as Ahmed (2015) argues, 'we need to give problems their names' (p. 8). As such, while troubling, her detailed recollection - everything from 'when I didn't stop you, you slid your hand across my belly. Your thumb touched the bottom of my bra and your pinky touched the top of my underwear' (p. 263) to 'I felt a shift in the water' (p. 264)-demonstrates how difficult it is to willfully 'come to voice' about rape. As Wunker (2016) states, 'Here's the thing: we don't know how to talk about rape. We don't know how to differentiate between different experiences of rape' (p. 60). Even though Hannah had recently witnessed rape, she can't name it for herself.

Despite this, Hannah demonstrates resistance in the defiant, detailed recalling of the event and 'coming to voice' by calling out her attacker. Because she knows that the tapes will be heard after her death, she also saves herself from the fallout - from 'the frustration of being found frustrating! Oh the difficulty of being assumed to be difficult!' - allowing herself to be 'mouthy'; after all, being willfully 'mouthy' is 'when we say what others do not want to hear' (Ahmed, 2014, p. 154). As such, her 'mouthy' 'coming to voice' is wholly uninterrupted, and free from silencing. For example, she anticipates her listeners' discomfort, seemingly relishing in it during her grisly retelling: 'I'm sorry. Is this getting too graphic for some of you? Too bad' (p. 265). Here, especially with the retort 'Too bad,' Hannah is unwaveringly 'a willful girl-child, the one who insists on getting her own way' (Ahmed, 2014, p. 21); she intends to foster a willfulness of 'not willing to cease' (Ahmed, 2017, p. 232) - a willfulness 
that 'travels, as a relation to others, to those who come before, to those who come after' (Ahmed, 2014, p. 143). Further, Ahmed (2017) also muses that 'Maybe there is a relation between willful and snapful' (p. 190); Hannah's 'Too bad' (Asher, 2007, p. 265) is snappy, and 'To be snappy is to be 'apt to speak sharply or irritably'... it has bite' (Ahmed, 2017, p. 190). As such, this moment might represent Hannah as a 'snappy' willful girl-child whose 'snappiness might be required to right a wrong' (p. 190) - her biting comment demonstrates her resilience, 'a technology of will' (p. 189).

Bryce - overtly characterised as a rapist and embodying a hostile attitude towards women is a undoubtably an horrific YA villain. What makes his and Tyler's characters especially terrifying, however, is the degree to which their characters are suggestive that a thriving rape culture is a key marker of adolescent experience. Though a terrifying reality of patriarchy, Hannah's resistant 'coming to voice' as the willful girl-child provides an example of how survivors might 'flip the gaze' and speak back to their oppressors, even in the face of hostile sexism.

\section{Challenging benevolent sexism: Hannah's optic agentic power over Clay}

\section{Caretaker Clay}

Clay is parttime narrator, he largely presents as a heartbroken witness to Hannah's métissage, and Hannah tells him, 'Clay, honey, your name does not belong on this list' ( $p$. 200). Nevertheless, he tries to 'save' Hannah rather than honor her, and as such can be read as a demonstration of benevolent sexism. Clay's inclination is to protect, defend, and sometimes, to admonish; he reads as someone who does not see Hannah as independent or as capable of controlling her own narrative. Rather, he seems to understand her willfulness 'as [a kind of] lawlessness' (Ahmed, 2014, p. 67).

Clay's benevolent sexism often presents discursively, in smaller moments. For instance, in one such moment, Clay is befuddled when Hannah admits that she enjoys learning makeup tips. He counters: 'you never wore makeup, Hannah. You didn't need it' and then, still 
stunned, asks, 'You wore makeup?' (p. 120). Although this might seem innocuous, what this moment demonstrates is that Clay holds tightly to the idea of Hannah's beauty as 'pure' (Becker \& Swim, 2011, p. 228) - a clear marker of benevolent sexism. As another example, when Hannah reveals that she found writing theraputic:

‘I did that for a while. Poetry, not a therapist' (p. 176),

Clay immediately quips,

'Maybe a therapist would have helped, Hannah' (p. 176).

Here, he completely dismisses her self care. Similarly, even as Hannah wryly jokes about vulnerability in poetry class:

'Expose yourself,' they said. 'Let us see your deepest and your darkest.' My deepest and darkest? What are you, my gynecologist?' (p. 182)

Clay passes judgement. He quickly admonishes her, seemingly trying to shut down her resistance by simply saying: 'Hannah.' (p. 182), exasperated. Considering that Hannah repeatedly speaks about sexual violence, this joke involving her vagina demonstrates that she is not only witty, but also, she is somewhat fearless. Arguably, this is another manifestation of how Hannah 'comes to voice' - she 'speaks freely' (hooks, 1994, p. 148). As such, Clay's shaming here is startling, almost as if he is trying to edit Hannah - to stop her, warning that she's crossed a line of his determining. Here, we can see how to be willful is synonymous with being a problem. Clay's inference about the inappropriateness of her joke is particularly disappointing because even after listening to all of the other far more difficult pieces of her story, it is troubling that he takes issue with this. His quick judgement is also a dismissal, demonstrating that is is not 'really taking seriously what [Hannah] says' (Scapp in hooks, 1994, p. 151), even though this joke speaks volumes. Clay is more concerned with 
putting Hannah in her place, taking up the 'Benevolent sexist ideology [that] reinforces power differences between women and men' (Becker \& Swim, 2011, p. 228).

Later, Hannah realizes that Clay doesn't trust her judgement; while working together at the movie theatre, Hannah insists that she sees Bryce for the dangerous person he is but Clay is sceptical. While Bryce is on a movie date, his partner suddenly bolts and from the concession stand, and they witness her teary exit. When Hannah assures Clay, 'I know who [Bryce] is, Clay. I know what he's like. Believe me,' he doesn't really; Clay asks, 'then why'd you keep talking to him?' (p. 148). Hannah pauses, perhaps pondering how much she is now willing to share. Clay then recognizes that Hannah's upset with him and admits:

'I couldn't raise my eyes to face her. I didn't want to see a look of disappointment or frustration in her eyes. I didn't want to see those kind of emotions directed at me' (p. 148).

Hannah then finally affirms, 'You don't need to watch out for me, Clay' (p. 148) - ultimately calling out his benevolent sexist behaviour - and yet, it is clear that he never does respect this point, especially after she's died.

Clay's benevolent sexism is especially exposed during Hannah's taped message to him. Hannah first acknowledges that she knows about Clay's strong romantic feelings, beginning the tape with 'Romeo, oh, Romeo. Wherefore art thou, Romeo?' (p. 197). This is significant because, arguably, Shakespeare's Romeo is benevolently sexist; as Hammond and Overall (2017) begin their paper on dynamics of sexist attitudes in intimate relationships, they open with a quote from the second act of the play, as:

Romeo's speech to Juliet exemplifies the devotion that benevolent sexism offers women: Romeo would travel across the ocean for Juliet-yet Romeo refers to Juliet as "merchandise," illustrating that this romantic depiction of intimate 
relationships promotes inequality between men and women. (Hammond \& Overall, 2017, p. 120)

Hannah's allusion is thus very telling, perhaps subversively revealing that while she doesn't harbour anger towards him, she is nevertheless attuned to his sexism. Hannah admits: '। [never] said to myself, Clay Jensen... he's the one' (Asher, 2007, p. 198), which might shed light on why Clay seems keen on so tightly controlling her story. Next, ironically, she says, 'I'm not even sure how much of the real Clay Jensen I got to know over the years' (p. 198) a surprising revelation, considering how well Clay seems to know her, perhaps through his paternalistic protective efforts. Hannah's tape also reveals her awareness that Clay somehow knows her better than she knows him, as she reports: 'my ears perked up whenever I heard his name. I guess I wanted to hear something - anything - juicy' (p. 199). As such, vying for this 'juicy' morsel suggests that Hannah sensed a power imbalance begging for correction - to have something to wield over him, should she need it.

Overall, while Clay may love Hannah, it is a form of love rooted in problematic, patriarchal ground - as an endorser of benevolent sexism, he 'internalize[s] prescriptions to be [a] successful provider' thus exhibiting greater 'dependency-oriented support... which involves directly providing plans and solutions for female[s] and neglecting [their] abilities' (Hammond \& Overall, 2017, p. 123). Despite hearing Hannah's story, Clay was often distracted by trying to fix or correct her rather than to deeply honor her by listening carefully.

\section{Conclusion}

Ahmed (2014) asserts that not only is being willful ultimately about seeking happiness, but further, that 'Even suicide is an expression of the will to happiness' (pp. 3-4). Though this might be difficult digest, when considering Hannah Baker's experiences as she chronicles her métissage of messages, it rings true. Although Hannah died by suicide, she left a reckoning in her wake, signalling an important call to action - after all, willfulness is 'not simple or only 
celebratory' (p. 20). Through her 'coming to voice' process that teaches us to carefully attend to the our stories, Hannah's métissage helps with understanding willfulness as not merely 'a problem' (Ahmed, 2014, p. 30), but rather, as a powerful feminist tool - a way of 'doing' or 'crafting' (p. 133) that can enact resistance and change.

\section{References}

Ahmed, S. (2017). Living a feminist life. Georgia: Duke University Press.

Ahmed, S. (2015). Introduction: Sexism - a problem with a name. New Formations, 86(86), 513.

Ahmed, S. (2014). Willful subjects. Georgia: Duke University Press.

Ahmed, S. (2012). Whiteness and the general will: Diversity work as willful work.

PhiloSOPHIA, 2(1), 1-20.

Ahrens, C. E. (2006). Being silenced: The impact of negative social reactions on the disclosure of rape. American Journal of Community Psychology, 38(3), 263-274.

Alvi, M. (2008). Europa. Newcastle: Bloodaxe Books.

Asher, J. (2007). 13 Reasons why. USA: Razorbill.

Becker, J. C. \& Swim, J. K. (2011). Seeing the unseen: Attention to daily encounters with sexism as a way to reduce sexist beliefs. Psychology of Women Quarterly, 35(2), 227-242.

Caruth, C. (1995). Trauma: Explorations in memory. Maryland: John Hopkins University Press. del Guadalupe, M. \& Yancy, G. (2009). Critical perspectives on bell hooks. New York, NY: 2009.

Expo' sito, F., Herrera, M.C., \& Moya, M. (2010). Don't rock the boat: Women's benevolent sexism predicts fears of marital violence. Psychology of Women Quarterly, 34, 36-42.

Fraser, C. (2015). From "ladies first" to "asking for it": Benevolent sexism in the maintenance of rape culture. California Law Review, 103(141), 141-203.

Glick et. al. (2000). Beyond prejudice as simple antipathy: Hostile and benevolent sexism across cultures. Journals of Personality and Social Psychology, 79(5), 763-775.

Glick, P. \& Fiske, S. T. (1996). The ambivalent sexism inventory: Differentiating hostile and benevolent sexism. Journal of Personality and Social Psychology, 70(3), 491-512.

Hammond, M. D. \& Overall, N. C. (2017). Dynamics within intimate relationships and the causes, consequences, and functions of sexist attitudes. Current Directions in Psychological Science, 26(2), 120-125.

Hasebe-Ludt, E., Chambers, C. M., \& Leggo, C. (2009). Life writing and literary métissage as an ethos for our time. New York: Peter Lang Publishing Inc.

hooks, b. (1994). Teaching to Transgress: Education as the practice of freedom. New York, NY: Routledge.

hooks, b. (2015). Talking back: Thinking feminist, thinking Black. New York, NY: Routledge. Lionnet, F. (1989). Autobiographical voices: Race, gender and self-portraiture. Ithaca, NY: Cornell University Press. 
Marshall, E. (2009). Girlhood, sexual violence, and agency in Francesca Lia Block's "Wolf." Children's Literature in Education, 40(3), 217-234.

Mulvey, L. (1975). Visual pleasure and narrative cinema. Screen, 16(3), 6-18.

Ronnberg, A. \& Martin, K. (2010). The book of symbols: Reflections on archetypal images. Cologne, Germany: TASCHEN.

Simpson, H. (2014). [Review of the book Willful subjects by Sara Ahmed]. College Literature, 43(4), 749-752.

Valenti, J. (2016). Sex object. New York, NY: HarperCollins.

Valdivia, A. N. (2002). bell hooks: Ethics from the margins. Qualitative Inquiry, 8(4), 429-447. Wunker, E. (2016). Notes from a feminist killjoy: Essays on everyday life. Toronto, On: BookThug.

Zuss, M. (1997). Strategies of representation: Autobiographical métissage and critical pragmatism. Educational Theory, 47(2), 163-180.

\section{Biographical Note}

Amber Moore is a SSHRC-funded PhD candidate and Killam Laureate at the University of British Columbia, studying language and literacy education with the Faculty of Education. Her research interests include adolescent literacy, feminist pedagogies, teacher education, and trauma literature, particularly YA sexual assault narratives. She also enjoys writing poetry and creative nonfiction. Email: amberjanellemoore@gmail.com 